\title{
FAKTOR - FAKTOR YANG MEMPENGARUHI INTENSI ENTREPRENEURIAL PADA SISWA DAN MAHASISWA DI SURABAYA
}

\author{
Krismi Budi Sienatra \\ Alumni Universitas Ciputra \\ Metta Padmalia \\ Alumni Universitas Ciputra
}

\begin{abstract}
Abstrak :
Penelitian ini bertujuan untuk melihat pada tahap awal lahirnya sebuah bisnis atau pada tahapan konsepsi dan persiapan. Secara lebih spesifik, tujuan dari penelitian ini adalah mengembangkan dan menguji secara empiris determinan intensi kewirausahaan menggunakan variabel karakteristik entrepreneur seperti umur, pendidikan, kompetensi, jenis kelamin, status pekerjaan, background orang tua, kemampuan melihat peluah dan kegigihan sebagai faktor yang memprediksi. Sampel penelitian ini adalah siswa dan mahasiwa yang mendapatkan pendidikan tentang kewirausahaan secara formal di kota Surabaya. Analisis dilakukan berdasarkan model regresi logistik biner yang memperkirakan pengaruh dari serangkaian variabel prediktor pada intensi berwirausaha. Hasil regresi logistik menunjukkan hanya variabel usia, kompetensi, relasi network, dan kemampuan melihat peluang yang berpengaruh terhadap intensi berwirausaha. Hasil yang diluar perkiraan adalah background orang tua tidak berdampak pada intensi berwirausaha.

Kata Kunci : intensi entrepreneurial, modal sosial, entrepreneurship

Abstract:

This study aims to look at the early stages of the birth of a business or at the stage of conception and preparation. Specifically, the purpose of this study is to develop and test empirically the determinants of entrepreneurial intentions using entrepreneur characteristic variables such as age, education, competence, gender, job status, parental background, ability to see persuasion and persistence as a predicting factor. The sample of this research is students and students who get formal education about entrepreneurship in Surabaya city. The analysis is based on a binary logistic regression model that estimates the effect of a set of predictor variables on entrepreneurship intentions. Logistic regression results show that only the age, competence, network relations, and ability to see the opportunities that affect the intention of entrepreneurship.

Out-of-the-box results are the background of the parents not impacting the entrepreneurship intentions. Keywords: entrepreneurial intention, social capital, entrepreneurship
\end{abstract}

\section{PENDAHULUAN}

Pada dewasa ini penelitian tentang topik kewirausahaan menjadi daya tarik tersendiri bagi para peneliti. Hal ini juga didukung dengan banyaknya universitas di Indonesia hingga saat ini yang membuka program studi yang bertemakan kewirausahaan untuk pembelajaran mahasiswanya. Banyak penelitian telah menetapkan kontribusi penting dari kewirausahaan dalam pertumbuhan ekonomi dan pembangunan. Penelitian yang dilakukan mulai dari Rocha et al. (2005) hingga Kasseeah (2016) yang semuanya menemukan bukti adanya hubungan antara tingkat aktivitas kewirausahaan dengan pertumbuhan dan pembangunan ekonomi. Fokus dari penelitian ini bukan untuk mengeksplorasi hubungan antara aktivitas kewirausahaan dan tingkat pertumbuhan ekonomi. Kami disini berpendapat bahwa sebelum lebih fokus pada menganalisis dampak kewirausahaan terhadap pertumbuhan dan pembangunan, adalah penting untuk memahami faktor-faktor yang menentukan kewirausahaan. Studi dari penentu kewirausahaan telah menekankan tiga perspektif yang berbeda yaitu variabel kelembagaan termasuk ketersediaan sumber daya, peraturan, insentif, variabel budaya dan variabel karakteristik pribadi (Gianetti, 2004). Penelitian ini mencoba untuk memahami faktor fundamental yang mendorong intensi kewirausahaan di tingkat mikro dengan mempelajari karakteristik individu.

Penelitian ini mengacu pada karya Grilo et al. (2008) yang menguraikan proses dari pengambilan keputusan kewirausahaan yang memungkinkan efek penentu yang bervariasi dari seluruh tingkat keterlibatan keputusan berwirausahan. Seorang pelaku dalam menyiapkan suatu bisnis adalah hasil dari serangkaian pilihan panjang yang kompleks. Hal ini adalah suatu proses dan bukanlah hasil dari satu pilihan penentu kewirausahaan yang tidak selalu sama pada setiap tingkat keterlibatan. Tingkat fase kewirausahaan telah populer telah diklasifikasikan mulai dari fase konsepsi, persiapan, pertumbuhan, remaja, dewasa dan penurunan (Grilo et al., 2008). Global Entrepreneurship Monitor (GEM) kemudian merangkum pengklasifikasian tahapan kewirausahaan kedalam pengkategorian yang lebih sederhana 
dimana tahap konsepsi dan persiapan diklasifikasikan kedalam fase discovery, tahapan pertumbuhan dimasukkan kedalam fase munculnya perusahaan, tahapan remaja dimasukkan kedalam fase baby business, dan tahap dewasa dimasukkan kedalam fase operasional.

Penelitian ini bertujuan untuk melihat pada tahap awal lahirnya sebuah bisnis atau pada tahapan konsepsi dan persiapan. Keputusan untuk memulai sebuah perusahaan baru diasumsikan direncanakan untuk beberapa waktu dan dengan demikian didahului dengan intensi untuk melakukannya. Oleh karena itu, intensi kewirausahaan diasumsikan sebagai cara memprediksi, meskipun tidak sempurna. Peneliti berpendapat bahwa sebelum faktor kelembagaan seperti lembaga keuangan pendanaan, hukum dan regulasi, dan skema insentif berperan dalam mempengaruhi keputusan individu untuk memulai bisnis. Keputusan memulai bisnis akan dipengaruhi oleh beberapa karakteristik intrinsik dari individu, yang muncul dalam bentuk jenis kelamin, usia, lokasi, pendidikan, pengalaman kerja dan persepsi subjektif. Hal ini bukan berarti faktor umum diluar karakter instrisik pelaku seperti aspek lembaga permodalan, peraturan pemerintah, regulasi dan hukum tidak mungkin mempengaruhi kemungkinan memulai bisnis. Namun, faktor tersebut belum tepat mempengaruhi pada tahap intensi awal usaha melainkan baru akan mempengaruhi pelaku bisnis pada proses pengembangan selanjutnya.

Tujuan dari penelitian ini ada dua. Pertama, untuk mengembangkan dan menguji secara empiris determinan intensi kewirausahaan yang tujuannya adalah bukan untuk mengusulkan wawasan yang sama sekali baru dalam hal variabel independen atau prediktor yang baru. Kyvler (2007) menggunakan variabel karakteristik entrepreneur seperti umur, pendidikan, kompetensi, jenis kelamin, dan keengganan risiko sebagai faktor yang memprediksi. Saraf (2015) menambahkan anggota keluarga, pekerjaan orang tua, kesempatan sebagai fakor prediktor intensi entrepreneurial. Sebaliknya, penelitian ini mencoba untuk mengintegrasikan variabel prediktor yang berbeda-beda yang dibahas dalam berbagai literatur sebelumnya oleh Kyvler (2007) dan Saraf (2015) yang digabungkan kedalam satu model.

Kedua, penelitian ini memberikan kontribusi untuk mengisi kesenjangan dalam literatur yang ada dengan memperkirakan hasil untuk data sampel besar yang telah ada di India yang telah dilakukan. Fitzsimmons dan Douglas (2005) telah melakukan studi banding di kewirausahaan sikap dan intensi di India, China, Thailand dan Australia. Tapi studi penelitian sebelumnya berbeda dengan penelitian yang dilakukan oleh peneliti dengan alasan berikut yaitu penelitian ini berfokus pada potensi intensi kewirausahaan dalam kurun waktu 2 tahun antara siswa dan mahasiswa yang memang sedang mendapat pendidikan entrepreneurship baik di sekolah ataupun universitas. Penelitian ini mengatasi masalah di atas dengan menggunakan model regresi logistik biner yang memperkirakan pengaruh dari serangkaian variabel prediktor pada intensi memulai bisnis dengan menggunakan responden pada siswa atau mahasiswa yang belajar tentang pendidikan entrepreneurship di Kota Surabaya. Faktor prediktor dalam penelitian ini menggunakan variabel demografi (contoh : umur dan jenis kelamin), modal manusia (contoh : pendidikan, status pekerjaan), latar belakang keluarga (contoh : pekerjaan orang tua, jumlah keluarga), dan modal entrepeneurial (contoh : relasi dengan entrepreneur, kemampuan melihat peluang, kompetensi, dan ketakutan terhadap kegagalan) untuk melihat intensi entrepreneurial. Dalam penelitian ini, peneliti mengusulkan bahwa perbedaan tingkat individu dalam hal karakteristik individu seperti umur, jenis kelamin, pendidikan, status pekerjaan, jaringan sosial, dan persepsi dapat mempengaruhi kemungkinan seorang individu memulai bisnis.

\section{LANDASAN LITERATUR}

Dalam beberapa tahun terakhir, faktor-faktor penentu kewirausahaan telah mendapat perhatian besar dalam penelitian secara empiris. Ada berbagai faktor penentu kewirausahaan, pada semua tahap, yang dieksplorasi dalam penelitian Kyvler (2007), Kyvler et al. (2008), Nga et al. (2010), dan Saraf (2015) menilai faktor penentu individu-tingkat aktivitas kewirausahaan di lintas negara dengan fokus pada persepsi individu dari diri mereka sendiri. Hasil penelitian mereka menunjukkan pentingnya variabelvariabel persepsi mempengaruhi keputusan individu untuk terlibat dalam kegiatan kewirausahaan. Grilo et al. (2008) mengeksplorasi penentu kewirausahaan di berbagai tingkat keterlibatan di Eropa dan Amerika Serikat. Davidsson dan Honig (2003) dalam penelitian mereka di Swedia menemukan bahwa orang yang memiliki orang tua yang terlibat dalam bisnis atau memiliki teman dekat atau tetangga dalam bisnis lebih cenderung menjadi pengusaha baru karena secara pribadi mengetahui orang yang telah memulai bisnis.

De Clercq dan Arenius (2006) dalam penelitian menemukan korelasi positif di kedua negara Belgia dan Prancis pada sampel mereka. Dalam analisis database Global Entrepreneruship Monitor (GEM) yang diambil sampel di 29 negara, Morales-Gualdron dan Roig (2005) juga 
menyimpulkan bahwa pengetahuan berelasi dengan seseorang yang telah memulai bisnis memiliki dampak positif pada keputusan orang untuk menjadi pengusaha. Menganalisis sampel yang sama, tetapi hanya negara Nordik dan hanya wanita, Arenius dan Kovalainen (2006) menemukan hal yang sama dalam hubungan kompetensi dan keberanian mengambil risiko cenderung mendorong seseorang menjadi seorang entrepreneur. Dalam bagian selanjutnya, kita meninjau literatur yang ada untuk faktor-faktor ini. Untuk tujuan diskusi, kita memiliki diklasifikasikan karakteristik ke dalam variabel kategori yang luas berikut.

\section{Variabel Demografi}

Usia. Kemungkinan memulai bisnis bervariasi dengan usia. Namun, temuan empiris menyatakan hubungan ambigu antara usia dan kemungkinan menjadi pengusaha yang baru. Klyver et al. (2007) dan Grilo et al. (2008) telah menemukan bukti bahwa usia memiliki dampak negatif pada kemungkinan berpikir untuk memulai sebuah bisnis. Blanchflower (2004) menunjukkan bahwa, meskipun probabilitas menjadi seorang pengusaha lebih tinggi ketika orang lebih tua, namun kemungkinan munculnya intensi memulai usaha dimaksimalkan kalangan individu muda (Minniti dan Arenius, 2006). Arenius dan deClercq (2005) menemukan bahwa usia menjadi tidak signifikan pada intensi entrepreneurial. Koellinger et al. (2005), dan Bonte et al. (2009) menunjukkan bahwa usia memiliki hubungan lengkung atau non-linear dengan start-up bisnis.

Jenis Kelamin. Kebanyakan penelitian menemukan bahwa pria memiliki probabilitas yang lebih tinggi terlibat dalam intensi memulai bisnis daripada wanita (Arenius dan deClercq, 2006 ; Grilo et al, 2008; Klyver et al., 2007). Terjesen et al. (2007) meneliti dimensi dan ukuran perbedaan budaya yang berdampak pada perbedaan gender dalam tingkat memulai kewirausahaan di seluruh negara. Hasil penelitiannya mengedepankan proposisi berikut : negara-negara dengan sektor pertanian yang lebih besar akan lebih cenderung memiliki tingkat yang lebih tinggi pada start-up bisnis untuk pria, dan negara-negara dengan sektor jasa yang lebih besar lebih mungkin untuk memiliki tingkat start up bisnis yang lebih tinggi terutama bagi perempuan. Bukti dari Rocha et al. (2005) juga mengusulkan bahwa negara-negara dengan kesenjangan upah akan lebih besar memungkinkan untuk memiliki tingkat start-up bisnis lebih tinggi dari untuk perempuan. Langowitz dan Minniti (2005) menemukan bahwa perempuan dan laki-laki memiliki kecenderungan yang sama dalam memulai bisnis.

Human Capital
Penelitian sebelumnya telah menyarankan pentingnya pengetahuan dan keterampilan individu dalam kewirausahaan (Davidsson dan Hoing, 2003). Pengetahuan dan keterampilan ini sering dijadikan satu kesatuan bersama dalam literatur dan dikenali sebagai modal manusia. Secara umum, dua dimensi utama modal manusia dibahas dalam literatur berhubungan dengan pendidikan dan status pekerjaan/ pengalaman.

Pendidikan. Temuan empiris untuk hubungan antara tingkat pendidikan individu dan kemungkinan untuk intensi berbisnis sangat meyakinkan. Beberapa peneliti berpendapat bahwa orang yang lebih berpendidikan lebih mungkin untuk mengidentifikasi peluang kewirausahaan, sedangkan yang lain berpendapat bahwa pencapaian pendidikan melibatkan biaya peluang dalam hal mencari kesempatan kerja yang lebih baik, sehingga mengurangi motivasi untuk mencari peluang start-up (Arenius dan deClercq, 2005). Hasil Arenius dan deClercq (2005) menunjukkan bahwa individu dengan tingkat pendidikan tinggi atau rendah akan melihat lebih banyak kesempatan dibandingkan dengan tingkat pendidikan yang hanya pada level menengah. Satu penjelasan untuk hubungan positif antara tingkat pendidikan yang rendah dan kemungkinan memulai bisnis karena dorongan keharusan yang dipaksa untuk menjadi wiraswasta karena tidak ada alternatif pekerjaan lain.

Status Pekerjaan. Hubungan antara status pekerjaan dan kemungkinan memulai bisnis masih belum menemukan kekonsistenan. Hal ini umumnya berpendapat bahwa status pekerjaan aktif atau pengalaman mempengaruhi pola pikir individu untuk pengetahuan, sehingga meningkatkan kemampuannya untuk memahami ide-ide dan peluang baru. Hal ini juga menciptakan jejaring yang positif yang memungkinkan mereka aktif di pasar tenaga kerja untuk memperluas jaringan profesional mereka dan mengembangkan jejaring yang dapat berguna kedepannya. Arenius dan deClercq (2005) membuat proposisi serupa dimana individu yang secara aktif terlibat dalam pasar tenaga kerja lebih cenderung memikirkan memulai bisnis, daripada mereka yang tidak. Argumen lain yang mendukung hubungan positif adalah bahwa individu biasanya terlibat dalam kegiatan kewirausahaan di lini bisnis di mana mereka telah memiliki beberapa langsung sebelum atau terkait pengalaman, yang biasanya dicapai melalui beberapa pengalaman kerja. Namun, pada saat yang sama, faktor status pekerjaan juga mungkin memiliki efek jaringan negatif dengan membatasi individu untuk berinteraksi dengan orangorang yang tidak memiliki pengalaman kewirausahaan di tempat kerja jika demikian akan 
terjadi.

\section{Latar Belakang Keluarga}

Jumlah Anggota Keluarga. Literatur empiris yang telah dilakukan tidak memberikan banyak bukti tentang dampak ukuran keluarga. Efek dari ukuran keluarga agak ambigu. rumah tangga yang lebih besar dapat mencegah individu terlibat dalam kegiatan kewirausahaan sejak dini termasuk pengambilan risiko (Shelton dan Daphne, 1996). Namun, di sisi lain, rumah tangga yang lebih besar juga dapat meningkatkan kemungkinan munculnya entrepreneur baru. Hal ini dapat dikatakan jika individu mungkin ingin mengurangi beban risiko keluarga dan memberikan kontribusi terhadap pendapatan keluarga. Kedua, ukuran rumah tangga yang lebih besar dapat menjamin ketersediaan tenaga kerja yang terjamin serta kepercayaan dengan tidak membocorkan informasi rahasia kepada pihak luar. Hal ini sangat kondusif di negara-negara yang memiliki tingkat bisnis milik keluarga yang tinggi. Akibatnya, ukuran keluarga cenderung memiliki dampak positif jika ada sejumlah kecil anggota tergantung di rumah tangga dan sebaliknya.

Pekerjaan Orang Tua. Status pekerjaan orang tua cenderung memiliki efek yang sama seperti yang dari efek role model. Marshall, Chlosta et al. (2010) dan Parker (2009) telah menyimpulkan bahwa keputusan untuk menjadi seorang pengusaha berkorelasi positif dengan memiliki orang tua yang juga pengusaha. Davidsson dan Honig (2003) menemukan dalam penelitian mereka di Swedia bahwa orang yang memiliki orang tua dalam bisnis lebih cenderung untuk menjadi pengusaha mengikuti jejak orang tua.

\section{Modal Kewirausahaan}

Douglas dan Shepherd (2005) mendefinisikan modal kewirausahaan mencakup dua dimensi yaitu kemampuan dan sikap kewirausahaan individu. sikap kewirausahaan adalah hal yang berkaitan dengan independensi, risiko, fleksibilitas, dan lain-lain. Kemampuan wirausaha termasuk mengintip peluang, penilaian yang baik, dan pemikiran inovatif. Dengan kata lain, kemampuan kewirausahaan adalah anugerah atau bakat dari pengetahuan terpendam (yang sulit untuk diekspresikan dan didokumentasikan). Hal ini biasanya diperoleh dengan cara pengalaman, networking, on-the-job training dan sebagai warisan / bawaan. Pengetahuan terpendam adalah pemberian istimewa yang menimbulkan heterogenitas antara pengusaha setelah mengakuisisi pengetahuan secara eksplisit. Pengetahuan khusus ini pada pengusaha tercermin dalam kewaspadaan dia terhadap rangsangan eksternal, kemampuan mengambil risiko dan kemampuan membuat keputusan.
Relasi Network. Penelitian kewirausahaan telah menunjuk pentingnya jaringan, personal dan sosial, untuk pengusaha (Arenius dan deClercq, 2005). Ardagna dan Lusardi (2008), Klyver et al. (2007), Davidsson dan Honig (2003), Arenius dan Kovalainen (2006), De Clercq dan Arenius (2006) menemukan bukti untuk efek yang kuat dari jaringan sosial / mengetahui pengusaha lain dalam menentukan perilaku kewirausahaan dan para peneliti tersebut berpendapat bahwa mengetahui pengusaha lain dan meningkatkan interaksi sosial dengan orang lain pada umumnya, merupakan sumber potensial untuk memperoleh informasi tambahan dan pengetahuan dan memahami ide-ide dan peluang baru.

Persepsi peluang. Dalam penelitian sebelumnya yang mengamati kesempatan merupakan karakteristik penting dari perilaku kewirausahaan. Klyver et al. (2008) menemukan bukti variabel ini menjadi prediktor kuat dari keputusan kewirausahaan. Ini penting bagi individu untuk memahami dan melihat peluang, yang mendorongnya untuk mulai memikirkan mendirikan sebuah bisnis.

Kompetensi. Koellinger et al. (2005) dan Klyver et al. (2007) menemukan bukti bahwa kepercayaan terhadap keterampilan start-up seseorang adalah prediktor yang paling penting untuk menjadikan munculnya pengusaha-pengusaha baru. Koellinger (2008) mengusulkan bahwa orang dengan tingkat rasa percaya diri yang lebih tinggi terhadap kompetensinya akan lebih mengeksploitasi peluang bisnis.

Ketakutan Terhadap Kegagalan. Indikator penting dari intensi kewirausahaan adalah sikap individu terhadap risiko. Proxy variabel telah digunakan di berbagai studi empiris. Sebuah mengurangi persepsi kemungkinan Kegagalan harus meningkatkan kemungkinan bahwa seorang individu akan memulai bisnis baru. literatur yang ada memiliki tidak ada bukti hasil sebaliknya.

\section{DATA DAN METODE PENELITIAN}

Populasi dan Sampel. Populasi dalam penelitian ini adalah siswa dan mahasiswa di kota Surabaya yang mendapatkan pembelajaran entrepreneurship. Karena jumlah populasi yang tidak diketahui jumlah pastinya maka penggunaan sampel penelitian menggunakan metode Hosmer dan Lemeshow (2000) dimana jumlah sampel minimal adalah sebanyak 10 kali dari jumlah variabel prediktor yang sebanyak 11 variabel, yaitu dengan jumlah sampel akhir 110 orang pada 6 
sekolah dan universitas di Surabaya.

Variabel Penelitian. Dalam penelitian ini definisi operasional adalah sebagai berikut yang diadopsi dari Saraf (2015).

Tabel1. Definisi operasional variabel

\begin{tabular}{|l|l|}
\hline \multicolumn{1}{|c|}{ Variabel } & \multicolumn{1}{|c|}{ Definisi Operasional } \\
\hline Jenis Kelajnin & $\begin{array}{l}\text { menggunakan variabel biner dimana } \\
\text { responden pria dikategorikan nilai '1' dan } \\
\text { responden perempuan nilai '0' }\end{array}$ \\
\hline Pendidikan & $\begin{array}{l}\text { Responden diminta untuk memberikan } \\
\text { pendidikan terakhir tertinggi mereka telah } \\
\text { dapatkan. }\end{array}$ \\
\hline Status pekerjaan & $\begin{array}{l}\text { responden diminta untuk memberikan status } \\
\text { pekerjaan mereka. Tujuh respon kategori } \\
\text { adalah sebagai berikut: bekerja penuh waktu, } \\
\text { bekerja paruh waktu, bekerja sendiri, tidak } \\
\text { bekerja, siswa/ mahasiswa }\end{array}$ \\
\hline $\begin{array}{l}\text { Jumlah anggota } \\
\text { keluarga }\end{array}$ & $\begin{array}{l}\text { responden menyebutkan jumlah anggota } \\
\text { keluarga di rumah yang membantu / } \\
\text { memberikan ide untuk entrepreneurial }\end{array}$ \\
\hline $\begin{array}{l}\text { Status pekerjaan } \\
\text { ayah }\end{array}$ & $\begin{array}{l}\text { responden diminta untuk memberikan latar } \\
\text { belakang pekerjaan ayah mereka, } \\
\text { dikelompokkan dalam : bisnis sendiri;, bekerja } \\
\text { kepada orang lain, dan tidak bekerja. }\end{array}$ \\
\hline $\begin{array}{l}\text { Status pekerjaan } \\
\text { ibu }\end{array}$ & $\begin{array}{l}\text { responden diminta untuk memberikan latar } \\
\text { belakang pekerjaan ibu mereka, } \\
\text { dikelompokkan dalam : bisnis sendiri;, bekerja } \\
\text { kepada orang lain, dan tidak bekerja. }\end{array}$ \\
\hline $\begin{array}{l}\text { Relasi network } \\
\text { dengan } \\
\text { entrepreneur lain }\end{array}$ & $\begin{array}{l}\text { responden ditanya apakah mereka secara } \\
\text { pribadi tahu seseorang yang memiliki } \\
\text { memulai bisnis dalam 2 tahun terakhir. }\end{array}$ \\
\hline $\begin{array}{l}\text { Memiliki } \\
\text { kompetensi }\end{array}$ & $\begin{array}{l}\text { responden ditanya apakah mereka diyakini } \\
\text { memiliki pengetahuan, keterampilan dan } \\
\text { pengalaman yang dibutuhkan untuk memulai } \\
\text { bisnis baru. }\end{array}$ \\
\hline $\begin{array}{l}\text { responden ditanya apakah takut akan } \\
\text { kegagalan akan mencegah mereka dari mulai } \\
\text { bisnis. }\end{array}$ \\
\hline Kegigan
\end{tabular}

Untuk menganalisis secara kuantitatif maka metode analisis data yang digunakan dalam penelitian ini adalah menggunakan analisis regresi logistik. Regresi logistik digunakan untuk melihat sejauh mana pengaruh sejumlah variabel prediktor (X) mampu memprediksi variabel respon (Y). Persamaan regresi logisitk dalam penelitian ini adalah sebagai berikut: $\operatorname{Ln} \frac{F}{1-F}=\mathrm{a}+\mathrm{b} X 1+\mathrm{b} X 2+\mathrm{b} X 3+\mathrm{b} X 4+\mathrm{b} X 5+\mathrm{b} X 6+$ $\mathrm{b} X 7+\mathrm{b} X 8+\mathrm{b} X 9+\mathrm{b} X 10+\mathrm{b} X 11+e$ (diadopsi dari Saraf, 2015 ; Kyvler, 2007) Dimana : Ln $\frac{F}{1-F}$ : intensi entrepreneurial

\section{HASIL DAN PEMBAHASAN}

Penelitian ini menggunakan jumlah sampel sebanyak 110 orang dari siswa dan mahasiswa yang memperoleh pendidikan kewirausahaan yang tersebar di sekolah menengah atas dan universitas di Surabaya. Pengujian hipotesis pada penelitian ini menggunakan regresi logistik untuk memprediksi tingkat keberhasilan dalam intensi berwirausaha. Variabel respon dalam penelitian ini adalah intensi berwirausaha dengan menggunakan variabel prediktor adalah usia, jenis kelamin, pendidikan, status pekerjaan, jumlah anggota keluarga, latar belakang pekerjaan ayah, latar belakang pekerjaan ibu, peluang menangkap usaha, relasi dengan entrepreneur lain, kompetensi, dan kegigihan. Pengujian hipotesis dalam penelitian ini dilakukan dengan menggunakan regresi logistik biner. Di dalam regresi logistik perlu dilakukan uji kelayakan model yaitu Hosmer and Lemeshow Test Goodness of Fit, likelihood, Cox and Snell's R square, dan Nagelkarke R square. Hasil model diagnostik dari regresi logistik ditunjukkan pada Tabel dibawah ini.

\section{Tabel 2. Model Diagnostic}

\begin{tabular}{|l|l|}
\hline Parameter Diagnostic & \\
\hline Hosmer \& Lemeshow Test & 0.291 \\
\hline Model chi square & $60.508^{* * * *}$ \\
\hline -2log likelihood & 19.297 \\
\hline Cox and Snell $R^{2}$ & 0.243 \\
\hline Nagelkarke ${ }^{2}$ & 0.453 \\
\hline Overall Correct Production & 84.1 \\
\hline
\end{tabular}

Dari tabel 2 menunjukkan hasil kelayakan model regresi yang ditunjuukan dengan nilai Hosmer and Lemeshow Test sebesar 0.291 yang lebih besar daripada nilai alpha 0.05 maka hipotesis nol tidak dapat ditolak dan berarti model mampu memprediksi nilai observasinya atau dapat dikatakan diterima sesuai dengan data observasi ata data dapat dikatakan fit. Hasil model chi square dengan nilai $\mathrm{p}$ value < 0.05 yaitu 0.000 memiliki paling tidak terdapat satu parameter regresi yang tidak sama dengan nol. Hasil Nagelkarke $\mathrm{R}^{2}$ sebesar 0.453 berarti kemampuan variabel prediktor dalam menjelaskan variabel respon adalah sebesar $45,3 \%$ dan terdapat $54,7 \%$ faktor lain diluar model yang menjelaskan variabel respon. Secara keseluruhan model penelitian ini mampu memprediksi hingga 84.15 untuk keakuratannya.

Hasil uji Regresi logostik menunjukkan dari pengujian variabel prediktor terhadap variabel respon 
yang berupa intensi berwirausaha dapat diketahui bahwa usia, status pekerjaan penuh waktu, jumlah anggota keluarga, peluang usaha, relasi network, dan kompetensi berpengaruh terhadap niat berwirausaha sedangkan variabel prediktor lain tidak memiliki pengaruh terhadap niat berwirausaha.

Secara keseluruhan, hasil penelitian dalam menguji pengaruh variabel usia menemukan bahwa koefisien usia menunjukkan hubungan yang signifikan positif dengan niat berwirausaha. Hal ini menunjukkan bahwa memulai bisnis baru akan semakin banyak atau berkembang seiring dengan bertambahnya usia. Hasil penelitian ini didukung oleh hasil penelitian Kyvler (2007) dan Saraf (2015) yang menemukan hasil signifikan namun negative karena disebabkan sampel penelitian yang dilakukan oleh mereka pada jenjang umur antara 30 tahun hingga 55 tahun. Penelitian ini menggunakan sampel pada siswa dan mahasiswa yang pada kisaran umur 17 tahun hingga 21 tahun. Pengujian variabel gender menunjukkan hasil yang tidak signifikan yang dapat diprediksi sebelumnya sesuai dengan penelitian Kyvler (2007), Kelley et al. (2012) dan Saraf (2015) yang menemukan hasil serupa. Hal yang menyebabkan gender tidak signifikan karena disebabkan obyek pada penelitian ini adalah siswa dan mahasiswa yang sejak awal memperoleh pendidikan kewirausahaan atas dasar pilihan mereka sehingga sejak awal para siswa dan mahasiswa memang sudah memiliki intensi untuk memulai sebuah usaha.

Hasil penelitian tidak menemukan dukungan untuk peran pendidikan dalam intensi berwirausaha. Hasil penelitian ini sama dengan yang diteliti oleh Koellinger et al. (2005) dan Saraf (2015) yang menemukan hasil yang serupa. Saraf (2015) berpendapat bahwa pendidikan dapat menyebabkan keterampilan yang sama-sama berguna baik bagi pengusaha dan pekerja dan tidak ada apriori antara pengaruh pendidikan terhadap pilihan antara berwirausaha dan bekerja secara umum. Penyebab lain mengapa pendidikan tidak memiliki dampak pada intensi berwirausaha disebabkan karena sampel yang menjadi obyek dalam penelitan ini semuanya adalah siswa dan mahasiswa yang sedang menempuh masa studi dan tidak menyertakan individu yang tidak pernah mengecap pendidikan formal dalam jenjang sekolah.
Status pekerjaan penuh waktu memiliki pengaruh positif sedangkan status pekerjaan paruh waktu, tidak bekerja dan bekerja di rumah tidak berpengaruh terhadap intensi berwirausaha. Penelitian ini didukung oleh hasil yang ditemukan Saraf (2015) yang menemukan hasil bahwa individu yang bekerja penuh waktu dan paruh waktu akan cenderung menjadi pengusaha baru. Penelitian ini mendapatkan hasil individu yang bekerja penuh waktu memiliki pengaruh menjadi pengusaha baru karena hampir $80 \%$ dari keseluruhan responden dalam penelitian ini menjalankan bisnis dimana bisnis yang dijalankan merupakan sebuah kewajiban yang bagian dari kurikulum pendidikan kewiraushaan yang didapatkan. Hal ini yang menjadi persepsi bahwa responden mengindentifikasikan dirinya telah bekerja secara penuh waktu.

Jumlah anggota keluarga dalam penelitian ini diketahui berpengaruh terhadap intensi berwirausaha. Hal ini berarti semakin banyak anggota keluarga akan menyebabkan intensi berwirausaha semakin besar. Penelitian didukung oleh penelitian yang dilakukan Kyvler (2007) dan Sienatra (2017) yang menemukan hasil serupa. Perusahaan yang melibatkan keluarga memperoleh keuntungan dari sistem interaksi antara keluarga, anggota individu dan bisnis terkait keuntungan dalam konsep keberkeluargaan. Di sini, mereka mendapatkan dukungan emosional dalam periode yang menegangkan dalam menentukan penggagasan bisnis bersama dan sumber daya keuangan yang diperlukan untuk memulai bisnis (Sienatra, 2017). Di sisi lain keluarga dapat menghasilkan semacam kemampuan kognitif dan non-kognitif yang dibutuhkan untuk menemukan dan mengeksploitasi peluang kewirausahaan (Bruin dan Ferrante, 2009).

Hasil mengejutkan dalam penelitian ini tentang status pekerjaan orang tua baik ayah dan ibu yang tidak memiliki pengaruh terhadap intensi berwirausaha baik status pekerjaan orang tua yang memiliki usaha sendiri ataupun yang sebagai pegawai. Dalam penelitian dan literatur terdahulu menunjukkan bahwa keputusan untuk menjadi seorang pengusaha berkorelasi positif dengan memiliki orang tua yang juga pengusaha. Hal yang berbeda dalam penelitian ini mungkin disebabkan karena orang tua dianggap sebagai relasi jejaring 
usaha dalam peranannya mendorong individu untuk merintis sebuah bisnis. Hal ini didukung dengan relasi network berpengaruh terhadap intensi berwirausaha dari responden. Relasi network yang dibangun menunjukkan mereka yang mengenal pengusaha lain mungkin akan lebih cenderung menjadi pengusaha daripada mereka yang tidak sama sekali. Anderson et al. (2007) memberikan gambaran bahwa relasi network ini berupa afiliasi, teman, keluarga yang merupakan jaringan sosial. Jaringan sosial merupakan kunci untuk membuka dan mendapatkan akses ke sumber lain karena mereka memfasilitasi komunikasi antara pihak-pihak atau personal yang mimiliki jaringan.

Kompetensi memiliki pengaruh terhadap intensi berwirausaha dimana responden merasa memiliki kemampuan dan ketrampilan untuk memulai sebuah bisnis. Kompetensi terdiri dari pengetahuan, ketrampilan, dan pengalaman yang menunjang memulai sebuah bisnis. Kompetensi merupakan bagian dari karakteristik entrepreneur yang harus dimiliki karena aspek ini mencangkup aspek kognitif, psikomotor, dan afektif (Kyvler et al., 2008). Seorang entrepreneur yang memiliki kompetensi didapatkan dari proses belajar baik di pendidikan formal dan informal akan menunjang kinerja dari entrepreneur dalam fase ideasi, fase munculnya perusahaan, fase baby business, hingga fase operasional. Variabel prediktor terakhir yaitu kegigihan tidak berpengaruh terhadap intensi berwirausaha. Hal ini berarti ketakutan ketika bisnis mengalami kegagalan lebih dari 1 kali menyebabkan seorang entrepreneur akan berpikir ulang lagi untuk memulai sebuah bisnis baru. Memulai sebuah bisnis baru bukan hal yang mudah karena memerlukan beberapa fase mulai dari ideasi, munculnya perusahaan, baby business phase, hingga fase operasional yang memakan waktu hingga 42 bulan hingga mencapai kemapanan. Fase yang panjang dan kesulitan dalam mengumpulkan sumber daya kembali menyebabkan responden dalam penelitian ini takut untuk memulai bisnis baru disamping itu usia responden dalam penelitian ini yang masih tergolong muda yaitu pada rentang usia 17 tahun hingga 21 tahun dimana masih belum memiliki kematangan dalam mindset entrepreneur. Hasil penelitian ini serupa dengan yang dihasilkan oleh Saraf (2015) dan
Sienatra (2017) dimana kompetensi dan relasi jaringan berpengaruh terhadap intensi berwirausaha. Sedangkan kegigihan yang tidak berpengaruh terhadap intensi berwirausaha hanya didukung oleh penelitian Saraf (2015).

\section{KESIMPULAN}

Artikel ini menganalisis faktor-faktor penentu keputusan untuk menjadi entrepreneur. Kami menggunakan model regresi logistik biner di mana variabel ekonomi dan demografis dipertimbangkan. Penelitian ini berkontribusi terhadap literatur yang ada dengan mensimulasikan berbagai faktor menjadi satu model empiris yang menunjukkan pengaruh yang signifikan dari berbagai karakteristik tingkat individu yang diidentifikasi seperti usia, status pekerjaan, modal sumber daya manusia. Hasil yang cukup menarik dalam penelitian ini bahwa background pekerjaan dari ayah dan ibu tidak berdampak pada intensi berwirausaha. Literatur yang sudah ada menjelaskan bahwa keputusan untuk menjadi seorang pengusaha berkorelasi positif dengan memiliki orang tua yang juga pengusaha. Namun, hasil penelitian ini yang tidak signifikan memberikan gambaran bahwa seorang individu dalam menentukan intensi berwirausaha bukan dari faktor orang tua melainkan dari faktor melihat peluang usaha, menjalin relasi network dan kompetensi yang dimiliki. Faktor modal kewirausahaan memberikan peranan lebih besar dalam meprediksi individu untuk memiliki intensi untuk berwirausaha.

\section{Daftar Pustaka}

1. Ardagna, S. et al. (2008). Explaining international differences in entrepreneurship: The role of individual characteristics and regulatory constraints (Working Paper No. 14012). National Bureau of Economic Research

2. Arenius, P., and Kovalainen, A. (2006). Similarities and differences across the factors associated with women's self-employment preference in the Nordic countries. International Small Business Journal, Vol 24, pp 31-59.

3. Bergmann, H. et al. (2007). The changing face of entrepreneurship in Germany. Small Business Economics, 28, 205-221.

4. Blanchflower, D. et al. (2004). What makes a young entrepreneur? (National Bureau of Economic Research Working Paper Series, 3252).

5. Bosma, N. et al. (2000). Determinants of successful entrepreneurship. Scientific Analysis of Entrepreneurship and SMEs. 
6. Davidsson, P., and Honig, B. (2003). The role of social and human capital among nascent entrepreneurs. Journal of Business Venturing, 18, 301-331.

7. De Clercq, D., and Arenius, P. (2006). The role of knowledge in business start-up activity. International Small Business Journal, 24, 339358.

8. Grilo, I. et al. (2008). Determinants of entrepreneurial engagement levels in Europe and the US. Industrial Corporate Change, 17, 1113-1145

9. Fitzsimmons, J. et al. (2005). Entrepreneurial attitudes and entrepreneurial intentions: A cross-cultural study of potential entrepreneurs in India, China, Thailand and Australia.

10. Giannetti, M. (2004). On the determinants of entrepreneurial activity: Social norms, economic environment and individual characteristics. Swedish Economic Policy Review, 11, 269-313.

11. Grilo, I. et al. (2008). Determinants of entrepreneurial engagement levels in Europe and the US. Industrial Corporate Change, 17, $1113-1145$.

12. Rocha, H. et al. (2005). Entrepreneurship: The role of clusters theoretical perspectives and empirical evidence from Germany. Small Business Economics, 24, 267-292.

13. Kasseeah, Harshana. (2016)," Investigating the impact of entrepreneurship on economic development: a regional analysis ", Journal of Small Business and Enterprise Development, Vol. 23 Iss 3 pp. 896 - 916

14. Klyver, Kim. (2007). Shifting Family Involvement During The Entrepreneurial Process, International Journal of Entrepreneurial Behavior \& Research, Vol. 13 Iss 5 pp. $258-277$

15. Klyver, K., Hindle, K., and Meyer, D. 2008. Influence of social network structure on entrepreneurship participation-A study of 20 national cultures. International Entrepreneurship and Management Journal, Vol 4 pp 331-347

16. Koellinger, P. (2008). Why are some entrepreneurs more innovative than others? Erasmus Research Institute of Management (ERIM) Report Series Research in Management

17. Minniti, M., Arenius, P., and Langowit, N. (2005). Global entrepreneurship monitor: 2004 report on women and entrepreneurship. Boston: Babson College and London Business School.

18. Morales-Gualdron, S. T., and Roig, S. (2005). The new venture decision: An analysis based on the GEM project database. International
Entrepreneurship and Management Journal, 1, 479-499

19. Nga, J. et al. (2010). The influence of personality traits and demographic factors on social entrepreneurship start up intentions. Journal of Business Ethics, 95, 259-282.

20. Saraf. N. 2015. What Determines Entrepreneurial Intention in India?. Journal of Entrepreneurship and Innovation in Emerging Economies Vol 1, No 1, pp 39-55

21. Sienatra, K.B. (2017). Keterlibatan Jaringan Sosial Dalam Proses Penemuan Bisnis. Jurnal of Business \& Applied Management, Vol 10, No 1. ISSN 1979-9543

22. Terjesen, S. et al. (2010). Female entrepreneurship in Latin America and the Caribbean: characteristics, drivers and relationship to economic development. European Journal of Development Research, $22,313-330$ 